

\section{DISCLAIMER}

This report was prepared as an account of work sponsored by an agency of the United States Government. Neither the United States Government nor any agency Thereof, nor any of their employees, makes any warranty, express or implied, or assumes any legal liability or responsibility for the accuracy, completeness, or usefulness of any information, apparatus, product, or process disclosed, or represents that its use would not infringe privately owned rights. Reference herein to any specific commercial product, process, or service by trade name, trademark, manufacturer, or otherwise does not necessarily constitute or imply its endorsement, recommendation, or favoring by the United States Government or any agency thereof. The views and opinions of authors expressed herein do not necessarily state or reflect those of the United States Government or any agency thereof. 


\section{DISCLAIMER}

Portions of this document may be illegible in electronic image products. Images are produced from the best available original document. 


\section{LEGAL NOTICE}

This report was prepared as an account of work sponsored by the United States Guvermment. Neither the Uniter States nor the Energy Research and Development Administration, nor any of their employees, nor any of their contractors, subcontractors, or their employees, makes any warranty, expressed or implied, or assumes any legal liability or responsibility for the accuracy, completeness or usefulness of any information, apparatus, product or process disclosed, or represents that its use would not infringe privately owned rights.

Printed in the United States of America

Available from the

National Technical Information Service

U.S. Department of Commerce

Springfield, Virginia 22161

Price: Printed Copy $\$ 4.50$ Microfiche $\$ 3.00$

Price Is Subject to Change Without Notice 
Printed

May 6, 1977
RFP-2588

UC-10 CHEMICAL SEPARATIONS

PROCESSES FOR

PLUTONIUM AND URANIUM

TID-4500-R65

\section{PLUTONIUM METAL BURNING 'FACILITY}

Chemistry Research and Development

D. E. Hausburg

INSTRUMENTATION AND STATISTICAL SYSTEMS GROUP

Chemical Operations

R. G. Leebl

SPECIAL RECOVERY GROUP

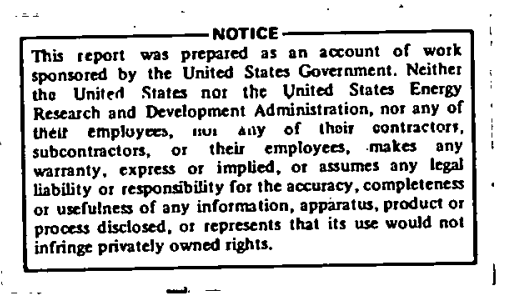

SUBJECT DESCRIPTORS

Plutonium Metal

Combustion

Plutonium Dioxide

Control Systems

ROCKWELL INTERNATIONAL

ATOMICS INTERNATIONAL DIVISION

ROCKY FLATS PLANT

P.O. BOX 464

GOLDEN, COLORADO 80401

Prepared under Contract EY-76-C-04-3533

for the

Albuquerque Operations Office

U.S. Energy Research and Development Administration 


\section{CON T E N T S}

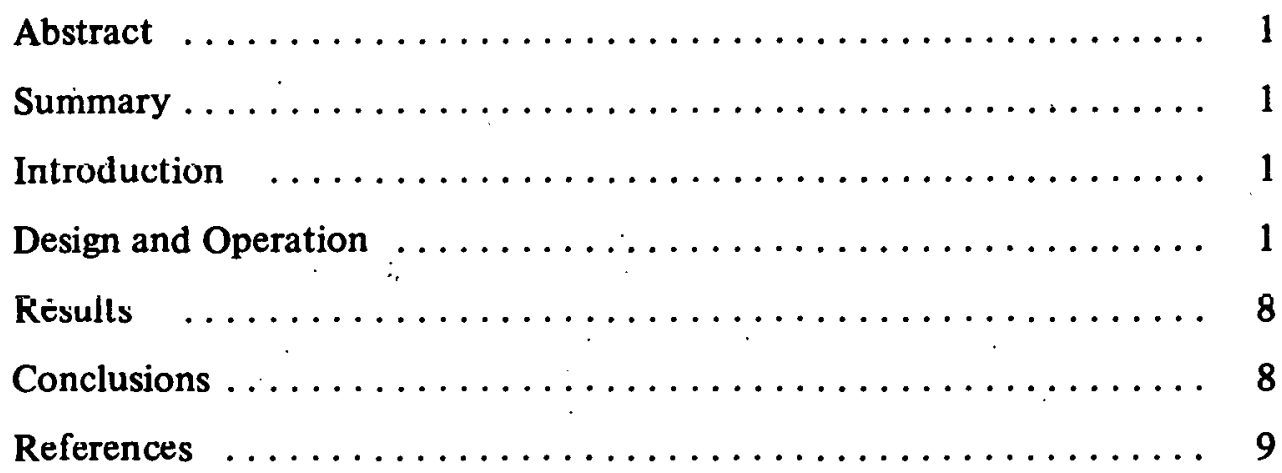

\section{ACK N O W LED GM E N T S}

The authors wish to thank W. J. Maraman and D. Harbur of the Los Alamos Scientific Laboratory for their technical assistance in the design of the water-cooled burning chamber. 


\title{
PLUTONIUM METAL BURNING FACILITY
}

\author{
D. E. Hausburg and R. G. Leebl
}

\begin{abstract}
A glove-box facility was designed to convert plutonium skull metal or unburned oxide to an oxide acceptable for plutonium recovery and purification. A discussion of the operation, safety aspects, and electrical schematics are included.
\end{abstract}

\section{SUMMARY}

A glove-box facility was designed to burn plutonium to the dioxide. The facility consists of two watercooled burning chambers that contain temperaturecontrolled heating elements to initiate the plutonium combustion. Two flow switches in the cooling water system prevent electrical power reaching the heating elements until water flow is established through each burning chamber.

An alarm system indicates a low liquid level in a secondary cooling-water holding tank. As an additional safety precaution, a high-temperature alarm on the exterior surface of the burning chamber is used as a backup system for possible failure of the circulating cooling-water system. Operator hand and/or glove burns are prevented by this redundant system.

For faster conversion of large masses of metal, additional air is supplied to each chamber from the building's compressed air supply. Rotameters installed in air pipelines entering the burning chambers indicate the rate of air flow to the chambers. To prevent pressurizing the glove box with this air system, an additional vacuum control is provided. A vacuum instrument and sensor closes a solenoid valve in the air supply pipeline. Simultaneously, a valve opens to the glove-box exhaust system. Warning lights and audible alarms also are included in the system.

\section{INTRODUCTION}

Plutonium skull metal and unburned oxide are generated at metal casting furnaces. Pyrolysis converts this material to an oxide acceptable for purification and recovery of the plutonium metal. For this pyrolysis step, a need has existed for the installation, in a glove box, of a burning facility with improved safety features.

Plutonium is a pyrophoric metal that burns in an air atmosphere to an oxide. Massive plutonium metal is relatively inert in dry air, but corrosive attack is accelerated by water vapor, with atmospheric-induced oxidation proceeding rapidly at moderate relative humidities. ${ }^{1}$ The possibility of an unwanted plutonium fire is always present when handling the metal-especially when the metal is finely divided or exists as a casting skull. ${ }^{2}$ In the alloyed state, the spontaneous ignition of plutonium has been observed by Musgrave at a temperature as low as $290^{\circ} \mathrm{C} .^{3}$

In a burning operation that is typical and routine, the metal is heated to about 300 to $350^{\circ} \mathrm{C}$ where the burning begins. Temperature spikes to $650{ }^{\circ} \mathrm{C}$ can occur. As the metal burns to the dioxide, large quantities of heat are liberated. Oetting reported that the heat of formation of plutonium dioxide $\left(\mathrm{PuO}_{2}\right)$ is $-242.87 \pm 0.38$ and $-252.4 \pm 1.1 \mathrm{kcal} / \mathrm{mole} .^{4}$ The former value was adopted as the heat of formation of $\mathrm{PuO}_{2}$ at $298^{\circ} \mathrm{K}\left(25^{\circ} \mathrm{C}\right)$. This large release of heat requires some form of dissipation during the burn cycle. Thus, water-cooled burning chambers are a requirement for safe operation.

These safety aspects, plus the chemical and physical properties of the material involved, were taken into consideration in the design of a glovebox facility for burning plutonium metal to the dioxide.

\section{DESIGN AND OPERATION}

The burning facility, as designed, has three separate glove-box sections with each section connected to the next by an airlock. A view of the glove-box 


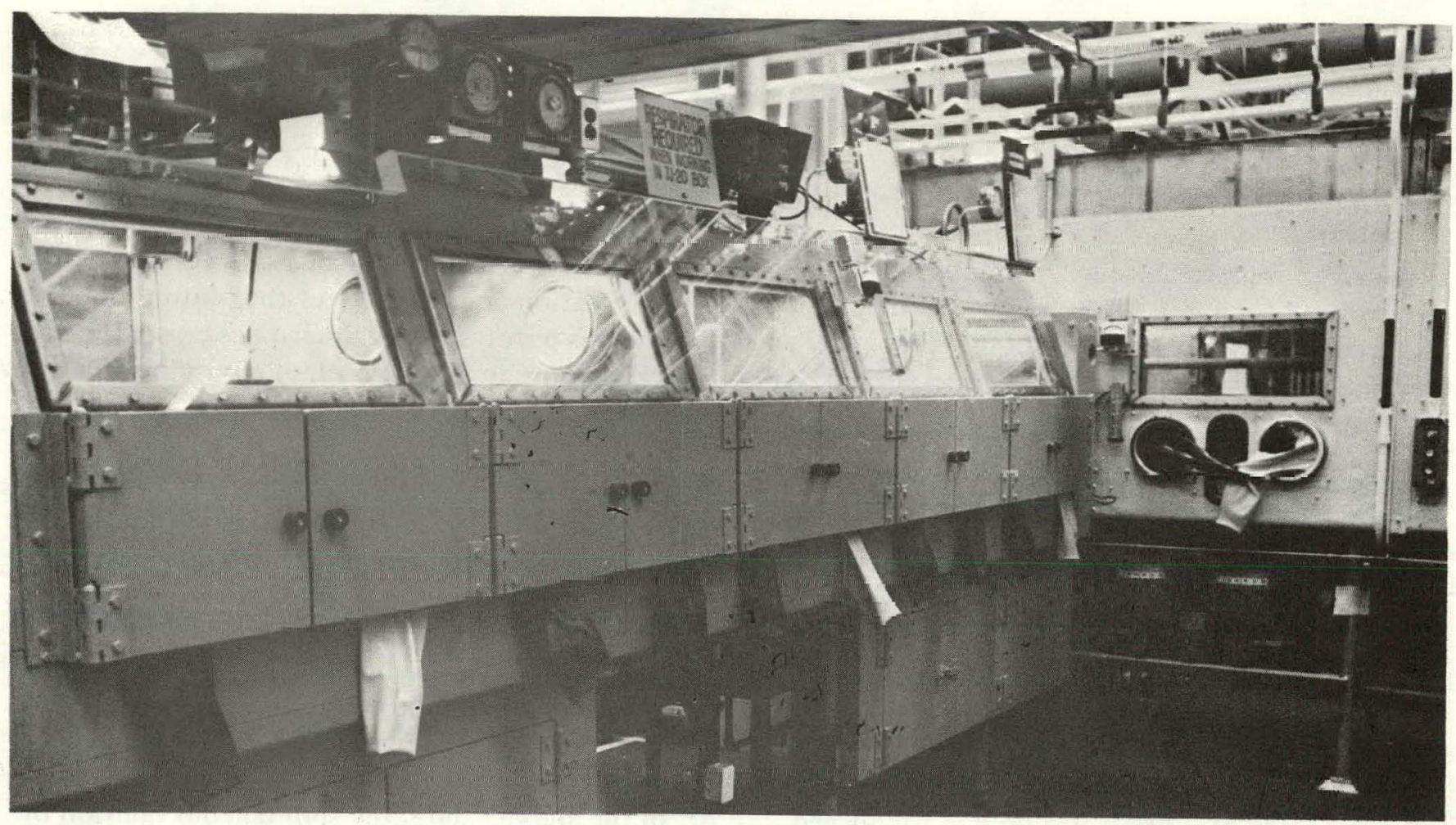

FIGURE 1. Metal-Burning Facility

$17113-8$

line is shown in Figure 1, and the process tlow diagram is given in Figure 2.

Material to be converted to an oxide is received through an airlock from an adjacent conveyor system. The material is then stored in a rack that is protected against any temperature that is too high (see Figure 3). Temperature sensors are beneath each storage location on the rack, and are connected to an over-temperature alarm system. A single container of material is then moved through the airlock to a glove-box section designed for the actual burning.

For the burning operation, the container's contents are transferred to an Inconel alloy burning pan (see Figure 4). The next step involves placing the pan on a heating element within the burning chamber, and inserting an Inconel sheathed thermocouple into the material. The burningchamber door is then closed and latched.
Each burning chamber is muunted un castors, which permits movement to the front or rear of the glove box. Castor gnides prevent any lateral movement of the chambers, thus precluding a nuclear safety condition.

For the burning operation, the chamber is moved to the rear of the glove box. The liquid level of the holding tank (refer to Figure 2) is checked for normal level, and Valves V-3, V-4, V-5, V-6, and $\mathrm{V}-7$ are opened. The circulating cooling water pump, M1, is energized by Switch S-2. The location of Switch S-2 is shown in Figure 5, which is a view of the burning-chamber control panel. Electrical Contacts FC-1 and FC-2 are closed when circulating cooling-water flow is established for each burning chamber (see Figure 6). Without the closure of these contacts, power cannot be supplied to the heating elements. 


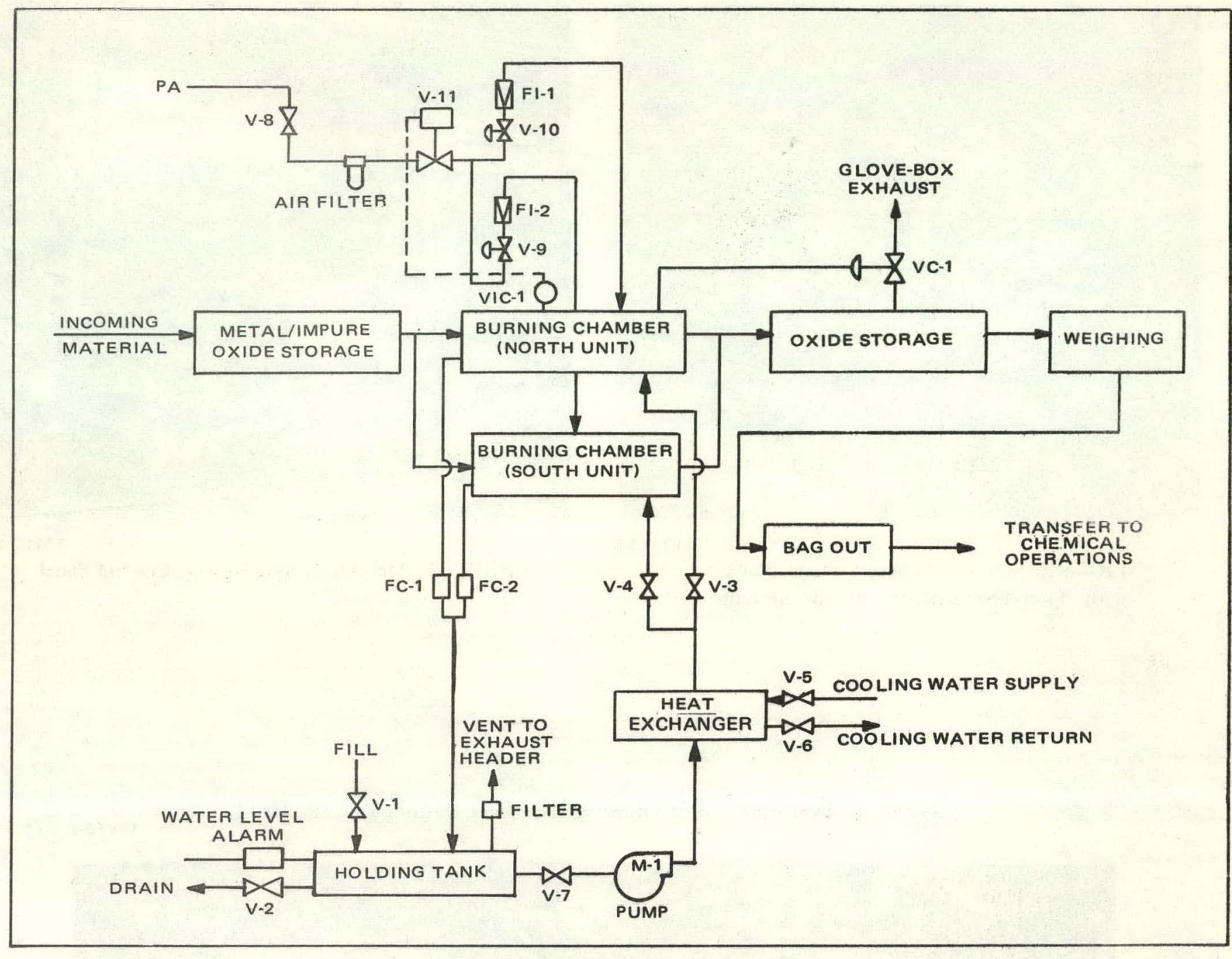

$$
\begin{aligned}
& \text { Legend } \\
& \text { PA - Compressed Air } \\
& \text { V - Valves } \\
& \text { FI - Flow Meter } \\
& \text { VC - Vacuum Controller } \\
& \text { FC - Flow Controller } \\
& \text { VIC - Vacuum Indicator Controller } \\
& \text { M - Circulating Cooling Water Pump }
\end{aligned}
$$

FIGURE 2. Process Flow Diagram

The alarm instruments, TIA-1 and TIA-2 (see Figures 7 and 8), for the burning chambers' exterior temperature should be checked for proper temperature indication. Ambient temperature of the circulating cooling water is the criterion temperature; an indication of $>66{ }^{\circ} \mathrm{C}\left(>150{ }^{\circ} \mathrm{F}\right)$ and a red light on the face of the instrument indicates either a malfunction of the temperature sensor or the instrument. In this event, maintenance personnel should be notified. The instruments should 


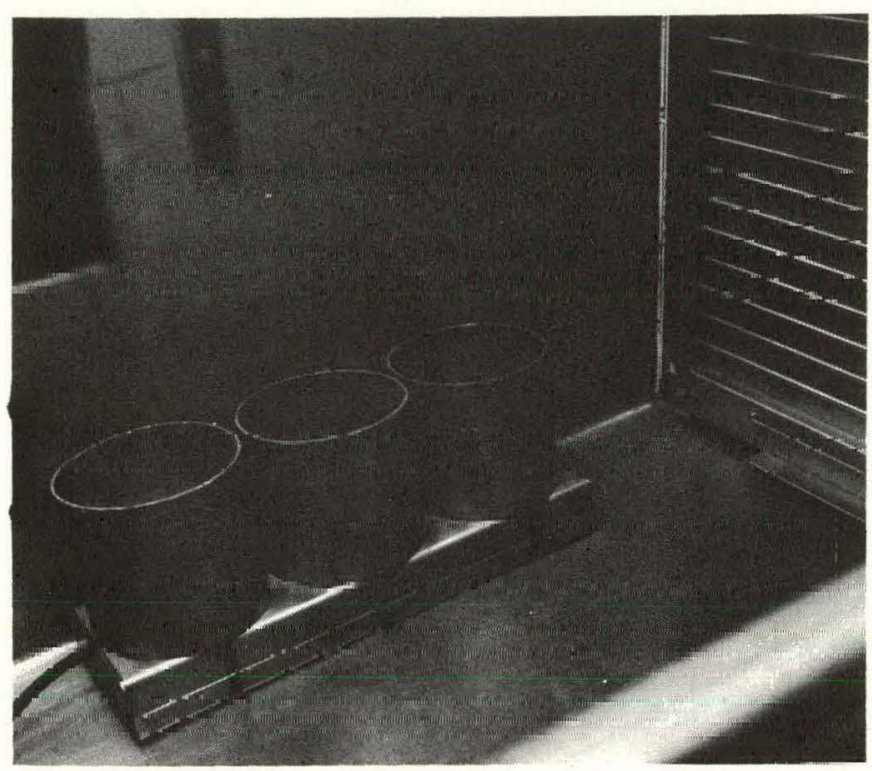

$17113-5$

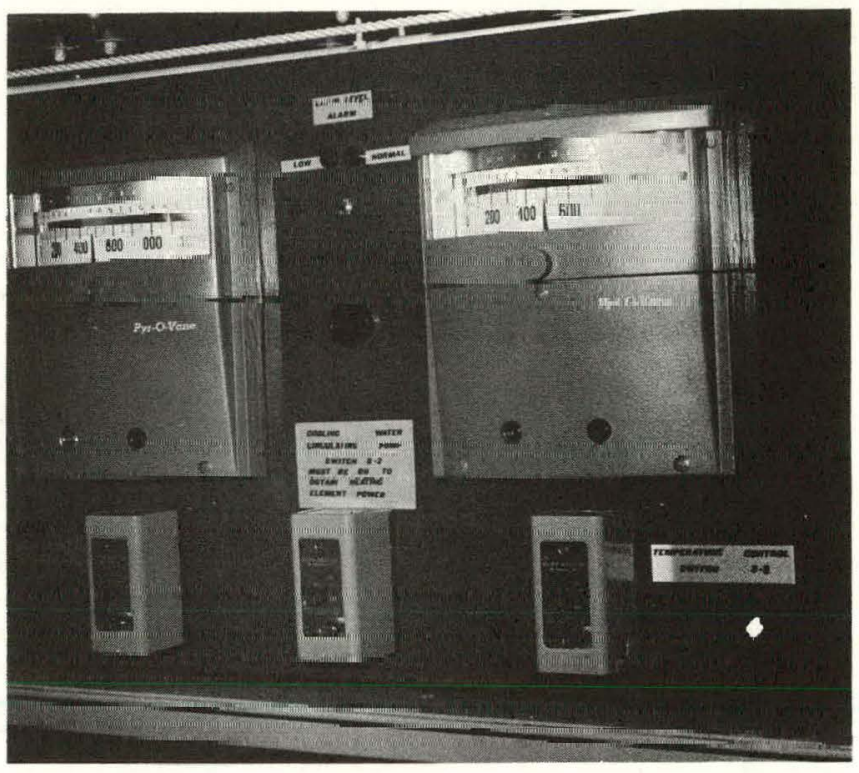

17113-11

FIGURE 5. Metal-Burning-Chamber Control Panel

FIGURE 3. Container Storage Rack with Over-Temperature Alarm System

FICIJRE 4. Two Water-Cooled Burning Chambers, Burning Pan, and Handle

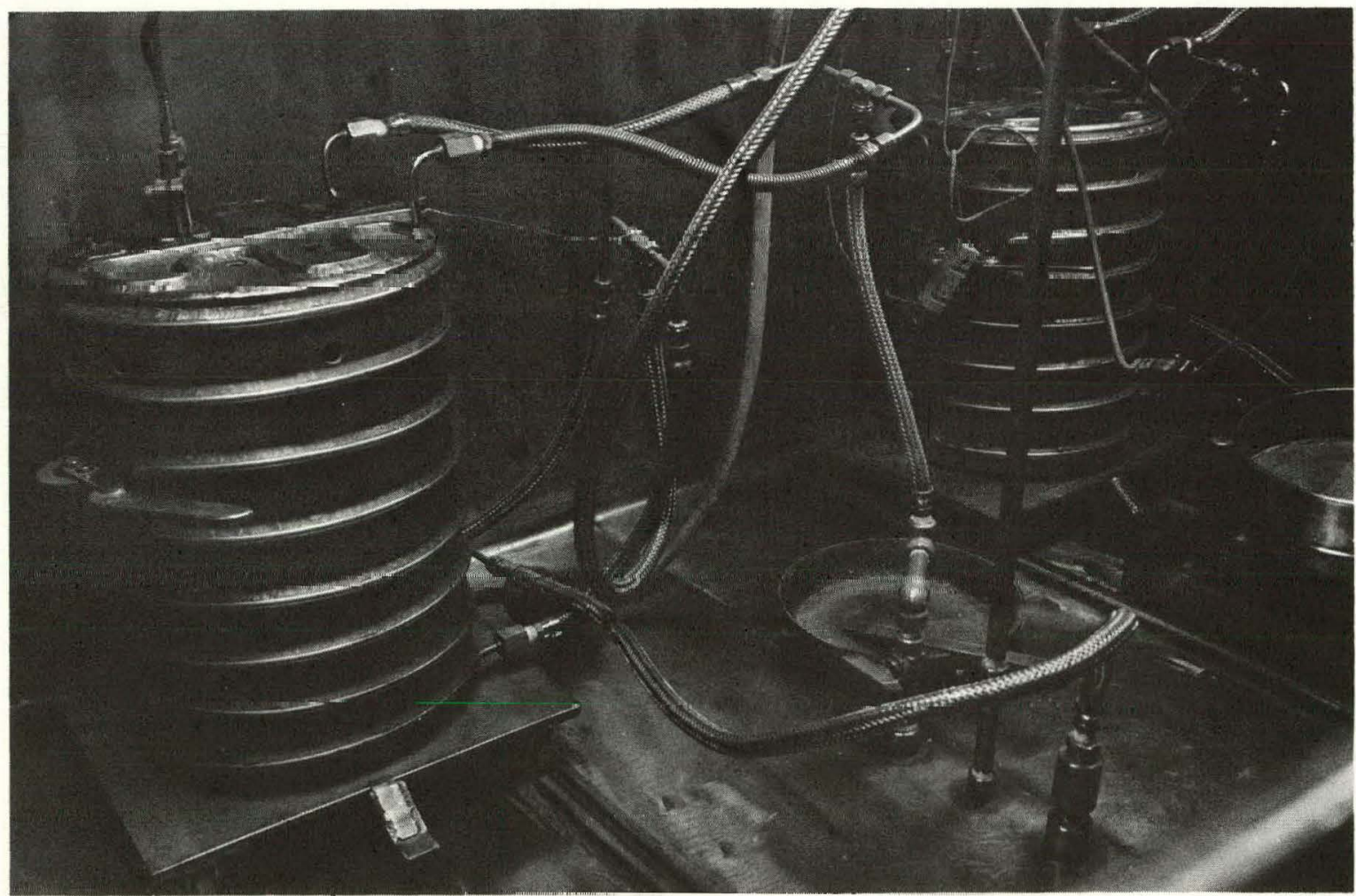


FIGURE 6. Electrical Schematic of Control Panel

$$
\begin{gathered}
\quad \text { Legend } \\
\text { A1 - Alarm, Mallory SC-110 } \\
\text { B1 - Rectifier, Varo Bridge, VE47 } \\
\text { C1 - Capacitor, Mallory MTV-50-DE-50 } \\
\text { EC - External Contacts for LLA-1 } \\
\text { F1 - Fuse-1/2 Amp } \\
\text { FC-1, FC-2 - Flow Control Switch, McDonnel Mod FS-1 } \\
\text { K1, K2 - Relay, P-B R40-E 1-X4-V50-6V DC } \\
\text { K3, K4 - Relays Allen Bradley, Mod 702L-AAD92 } \\
\text { L1, L2 - Lamp, Marco-Oak Sockets, Lamp No. 32B } \\
\text { LLA-1 - Liquid Level Alarm National Sonics, } \\
\text { Mod 300 Control Mod 30 Probe } \\
\text { M1 - Motor; Pump, Little Giant, 1/2 hp } \\
\text { S1, S3 - Switch, Allen Bradley Bul 600 Tax-216 with P-39 Heater } \\
\text { S2 - Switch, Allen Bradley Bul 600 Tax-216 with P-24 Heater } \\
\text { S4 - Switch, Grayhill Series 23 } \\
\text { TIC-1, TIC-2 - Temperature Indicating Controllers Honeywell } \\
\text { Tod 105C204-PS-22 } \\
\text { T1, T2 - Powerstats Superior, Mod 136B, } \\
\text { T3phenol Connector, 14B-010-01 } \\
\text { T3 - Triad Transformer F1BX }
\end{gathered}
$$

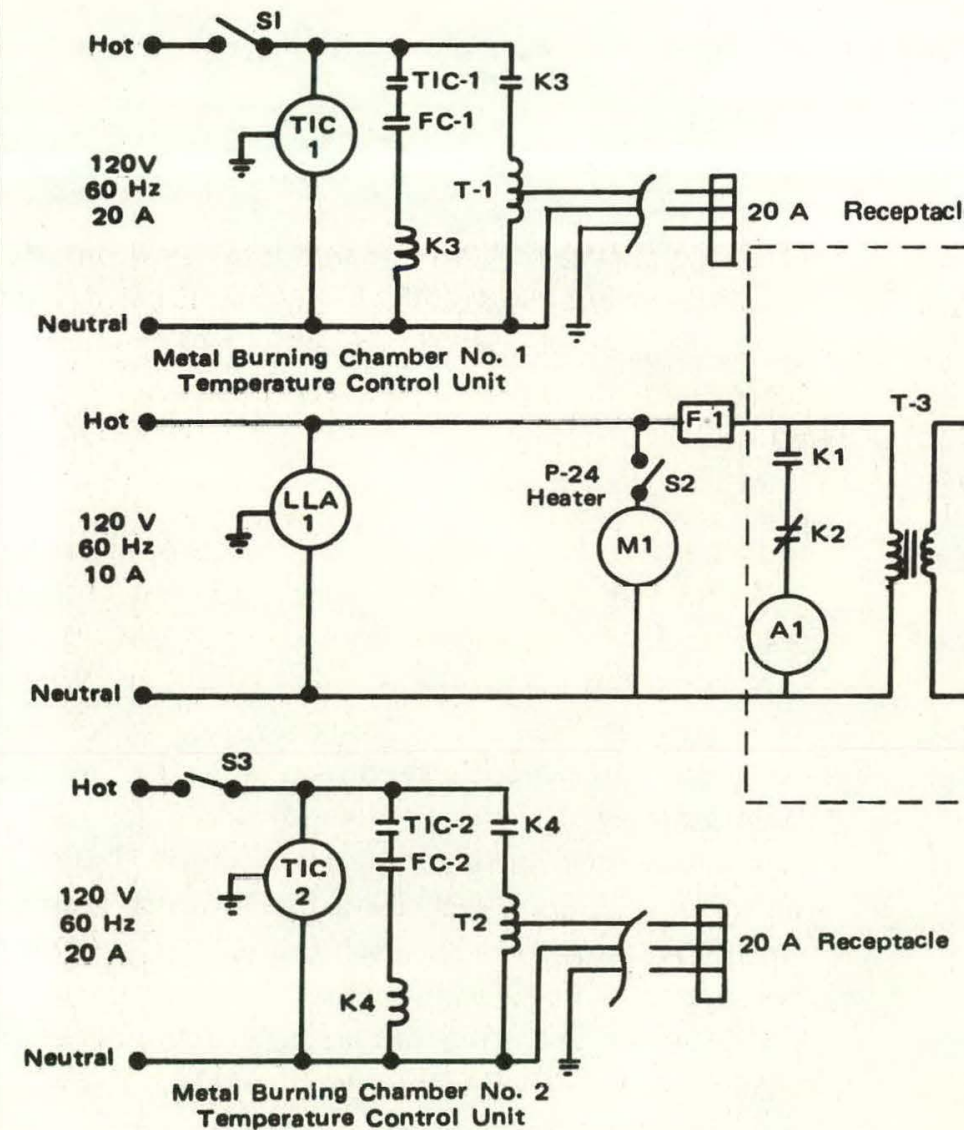




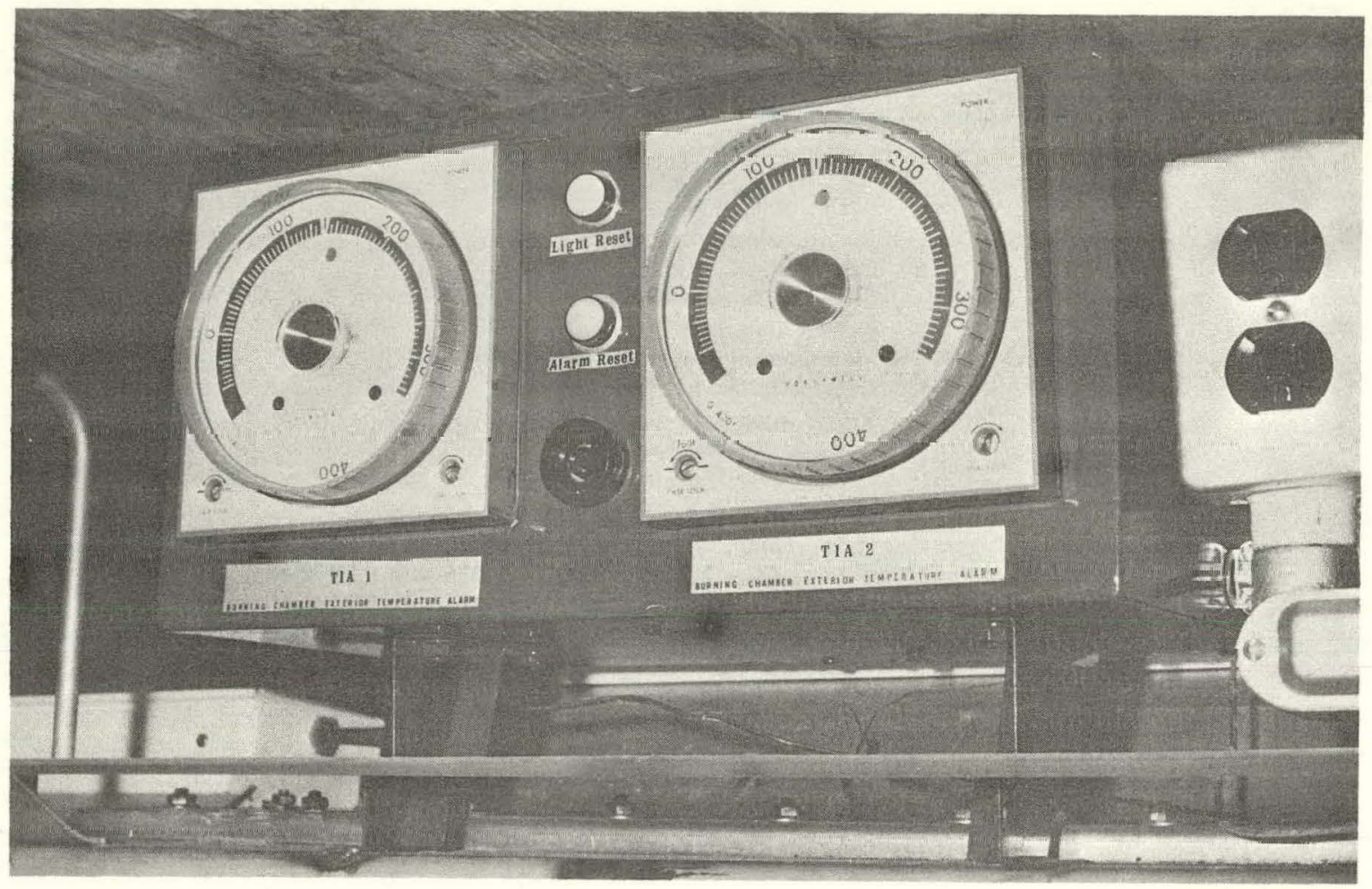

FIGURE 7. Temperature Alarm Panel for the Exterior of the Metal Burning Chamber.

$17113-9$

indicate approximately an ambient temperature for the circulating cooling water, and a green light should be present on the face of the instrument before proceeding.

Electrical power is applied to the appropriate heating elements with Temperature Indicating Controllers TIC-1 and TIC-2, and Power Switches S-1 and S-3. The temperature will rise until sustained ignition of the plutonium occurs and will continue to rise until the temperature controller setpoint is reached. The controller will control the electrical power to maintain the temperature of the setpoint. To aid oxidation during the burning period, the chamber door is opened, and the material is stirred with the Inconel* handle of the burning pan.

When large masses of metal are required to be reduced to oxide, additional air is supplied to each

\footnotetext{
*Trademark of Huntington Alloy Products Division, The International Nickel Co., Inc., Huntington, West Virginia.
}

burning chamber from the building's compressed air system (see Figure 9). Adjustment of Pressure Reducing Regulaturs V-9 or V -10 will produce the proper oxidation rate. The air flow rate can be noted by observing the air flow indicators, FI-1 and FI-2 (see Figure 2).

After the material is converted to an oxide, the burning pan is removed from the burning chamber, placed on the glove-box floor to cool, and electrical power is shut off to the burning chamber. When the oxide reaches room temperature, it is screened through a fine mesh screen into an 8801 Vollrath container. Large pieces of unburned material from the screening operation are removed and reburned. A lid is placed on the Vollrath container, which is transferred through the bulkhead door for storage in the oxide-storage section rack. The oxide is stored until 1400 grams per container are accumulated. The accumulated oxide is then weighed on a certified balance prior to being removed from the glove box and stored in the Production Control vault. 


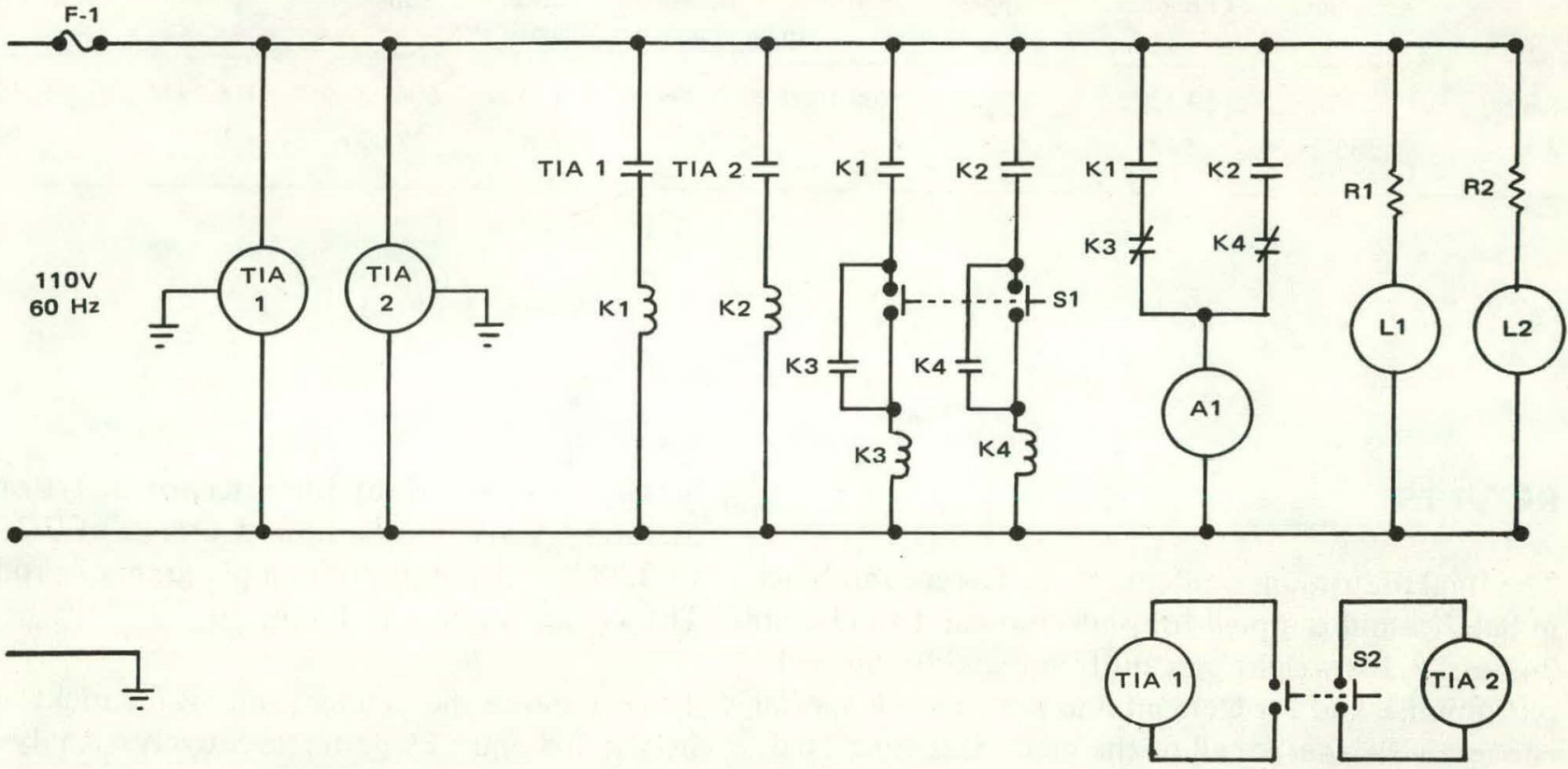

Legend

A1 - Alarm, Mallory Audible Electronic Signal Type SC110

F1 - Fuse Lamp

K1, K2, K3, K4 - Relay, Potter-Brumfield

L1, L2 - Lamp, Dialco 101-3830-0971-201 Lamp No. 328

Note 1 - Remote Reset Pushbutton Located on Panel

R1, R2 - Resistor, 27K Ohms

S1, S2 - Pushbutton Switch, Grayhill Series 23

TIA1, TIA2 - Temperature Indicating Alarm, Honeywell Mod R7351A1080

FIGURE 8. Electrical Schematic of Alarm Panel

FIGURE 9. Pressure Reducing Regulators

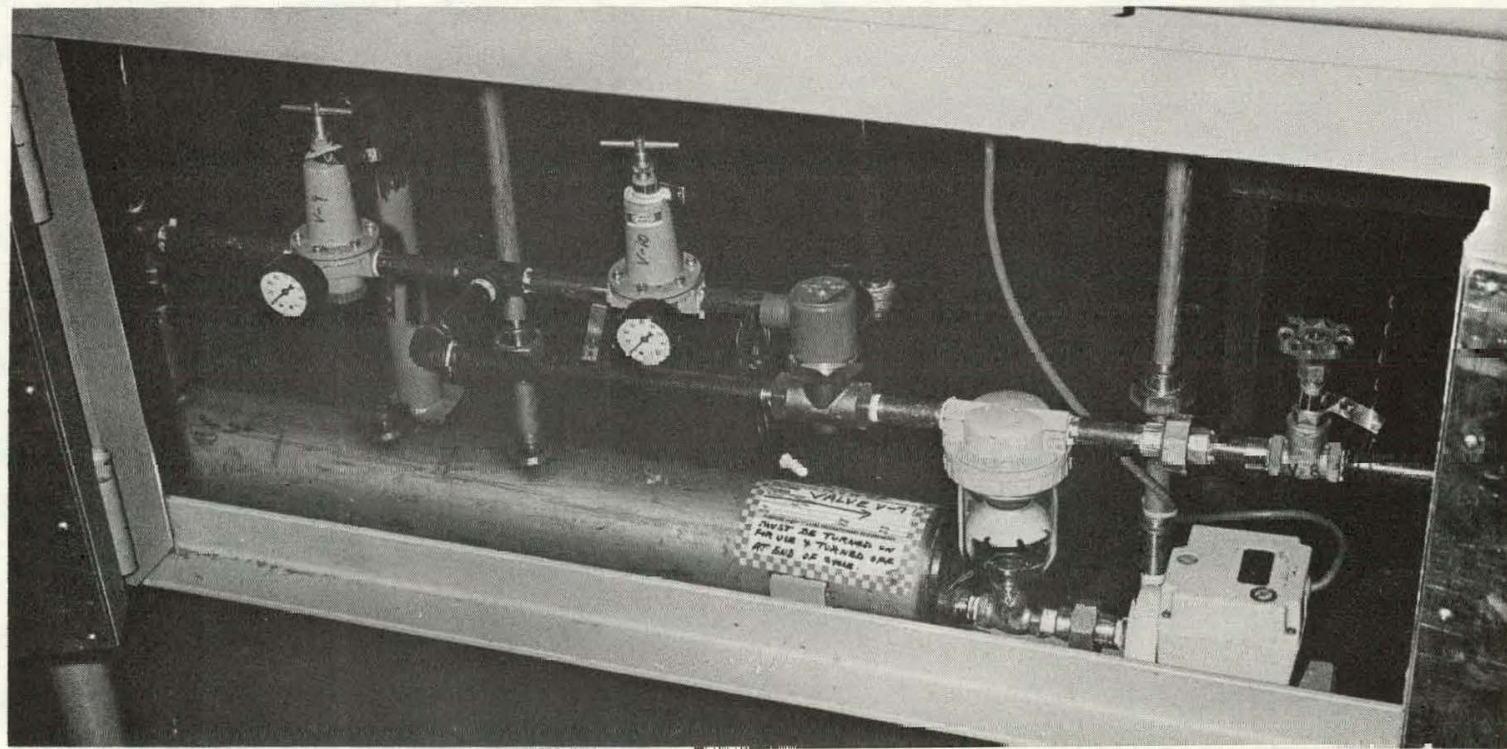


TABLE 1. Elemental Impurities in Sample Batches of Plutonium Oxide Product

\begin{tabular}{|c|c|c|c|c|c|c|c|c|c|}
\hline & Aluminum & Chromium & Copper & Iron & Nickel & $\begin{array}{l}\text { Silicon } \\
\text { nium }\end{array}$ & Tantalum & Carbon & Americium-24 \\
\hline Range & $66-275$ & $19-320$ & $\overline{100-500}$ & $\overline{200-1000}$ & $68-995$ & $21-480$ & $60-30,000$ & $186-8972$ & $119-264$ \\
\hline Average & 135 & 55 & 438 & 526 & 265 & 188 & 17,000 & 2881 & 168 \\
\hline
\end{tabular}

\section{RESULTS}

The final plutonium oxide product was accumulated in batches and sampled for plutonium and americium241 assay, for weight percent free metal (unburned plutonium), and for elemental impurities. Of special concern was whether all of the metal was converted to the oxide and to what extent constituents of the Inconel alloy metal were picked up by the plutonium oxide.

Sixteen batches of oxide were sampled for the amount of unburned (free) metal. In all cases, metal content in the oxide was less than $1 \mathrm{wt} \%$ (detectable limit). Also measured was decomposition outgas above $400{ }^{\circ} \mathrm{C}$. Those samples showing an outgas probably contained metal fluoride (from the calcium fluoride mold coating) and possibly graphite chips from the casting crucibles. Of the 16 samples taken, only nine showed any weight loss, and those averaged $\leqslant 0.5 \mathrm{wt} \%$.

Elemental impurities in the 16 batches of oxide are shown in Table 1. Only major constituents are tabulated. Tantalum is exceptionally high because of this element being picked up from the tantalum casting crucible and funnel during foundry casting operations.

The $\mathrm{PuO}_{\mathrm{X}}$ content of four batches of oxide was determined by analytical diffraction microscopy and by stoichiometry calculations. Results varied from $\mathrm{PuO}_{1.98}$ to $\mathrm{PuO}_{1.99}$. Traces of plutonium oxide fluoride (PuOF), and tantalum oxide $\left(\mathrm{TaO}_{2}\right.$ or $\mathrm{Ta}_{2} \mathrm{O}_{5}$ ) were observed in the oxide product. Plutonium assay was run on each of the 16 oxide batches using the X-ray fluorescence analytical method. Assay results showed a range of 0.759 to 0.983 grams of plutonium per gram of product. The average value was 0.846 .

Table 1 shows the average content for nickel and iron is 265 and $526 \mathrm{ppm}$ respectively. Analyses for plutonium casting metal historically has shown 100 to $200 \mathrm{ppm}$ nickel and 200 to $400 \mathrm{ppm}$ iron. Therefore, little pickup from the Inconel burning pans was seen. Visual inspection of the pans revealed little corrosive pitting or degradation from burning the plutonium metal.

Dissolution rates of plutonium oxide in a solvent mixture of $12.5 \mathrm{M}$ nitric acid $\left(\mathrm{HNO}_{3}\right)$ and $0.1 \mathrm{M}$ hydrofluoric acid (HF) are approximately 600 to 700 grams of uxide per hour using Production's plutonium recovery dissolution facility. No problems are encountered during the dissolution operation, and a 97 percent dissolution efficiency is obtained ( $3 \mathrm{~g}$ heel per $100 \mathrm{~g}$ oxide charge).

\section{CONCLUSIONS}

The plutonium metal-burning facility has been in operation for nearly four years and has permilled the safe production of oxide containing less than 1 percent unburned metal. The design has achieved efficient operation with no injury to operating personnel. Additional plutonium metal burning facilities have been constructed and installed for conversion of machine turnings to the dioxide. These facilities have incorporated the design described in this report. 
Maintenance to the burning facility consists of periodic replacement of the hot plates and repair of the flexible tubing used for cooling water supply and cooling water return to the burning chamber. The modified Chromalox hot plates* must be replaced approximately once every three months because of failure in the heating element.

*The hot plates were modified by placing one-inch-thick insulation material under the heating element and using metal terminal strips for conduction of power from the power supply cord to the heating element. Metal terminal strips (2) pass through the insulation into the thermally hot zone. This minimizes heat damage to the lower section of the hot plate where the electrical power cord connects.

\section{REFERENCES}

1. O. J. Wick. Plutonium Handbook, Vol. 1., Section 6.1. O. J. Wick, Editor. Gordon and Breach Science Publishers, London, New York, and Paris. (1967)

2. Ibid., Section 6.4 .

3. L. Musgrave. Product Integrity and Surveillance Group. Dow Chemical U.S.A., Rocky Flats Division, Golden, Colorado. Personal communication. (January 9, 1973)

4. F. L. Oetting. "The Chemical Thermodynamic Properties of Plutonium Compounds." Chem. Revs. 67. Pages 271-272. (1967) 


\section{THIS PAGE WAS INTENTIONALLY LEFT BLANK}

